\title{
Strategi Kebijakan Fiskal Terhadap Output dan Inflasi Pada Perekonomian Indonesia dalam Menghadapi Dampak Virus Covid-19
}

\author{
Ayu Feranika, Dini Haryati \\ Universitas Dinamika Bangsa Jambi, IAI Nusantara Batang Hari Muara Bulian \\ ayuferanika2@gmail.com
}

\begin{abstract}
This study aims to determine the fiscal policy strategy on output and inflation in the Indonesian economy in dealing with the effects of the covid virus 19. In this study, researchers chose to use descriptive research types, namely to explain an event whose operation revolves around data collection, data processing and data interpretation which is given a national meaning while still holding the principles of logic to form holistic conclusions. Data obtained through the study of literature, by reading and analyzing and analyzing a variety of literature, both in the form of documents, journals, publication data from the ministry of finance and from the official website that releases information that is relevant to research. While the data analysis is done by reducing, classifying, interpreting, and drawing conclusions. The Indonesian government adopted a comprehensive policy in the fiscal and monetary sector to deal with Covid-19. In the fiscal sector, the Government conducts a policy of refocusing activities and budget reallocation. From the revenue side, the government must pay attention to the contribution contribution from PPN and PPh Agency and from the expenditure side, the government must be able to pay attention to the realization of the use of these funds so that it is right on target and prioritizes the priority activities of the Covid pandemic prevention 19 To suppress the budget deficit.
\end{abstract}

Keywords- Fiscal Policy, Inflation, Indonesian economy, the impact of covid virus 19

\begin{abstract}
Abstrak- Penelitian ini bertujuan untuk mengetahui strategi kebijakan fiskal terhadap output dan inflasi pada perekonomian indonesia dalam mengahadapi dampak virus covid 19. Pada penelitian ini,peneliti memilih menggunakan tipe penelitian deskriptif, yaitu untuk menjelaskan suatu peristiwa yang operasionalisasinya berkisar pada pengumpulan data, pengolahan data dan penafsiran data yang diberi makna secararasional dengan tetap memegang prinsip-prinsip logika sehingga terbentuk kesimpulan yang holistik. Data diperoleh melalui studi literatur, dengan membaca dan menelaah serta menganalisa berbagai literatur, baik berupa dokumen, jurnal, data publikasi dari kementerian keuangan maupun dari website resmi yang mengeluarkan informasiinformasi yang relevan terhadap penelitian. Sementara analisa data dilakukan denganmelakukan reduksi, klasifikasi, pemaknaan hingga penarikan kesimpulan. Pemerintah Indonesia mengambil kebijakan yang komprehensif di bidang fiskal dan moneter untuk menghadapi Covid-19. Di bidang fiskal, Pemerintah melakukan kebijakan refocusing kegiatan dan realokasi anggaran.Dari sisi penerimaan, pemerintah harus memperhatikan pemberian kontribusi penerimaan dari PPN dan PPh Badan dan dari sisi pengeluaran, pemerintah harus mampumemperhatikan realisasi penggunaan dana tersebut agar tepat sasaran dan mengutamakan kegiatan prioritas pencegahan pandemik Covid-19 Untuk menekan defisit anggaran.
\end{abstract}

Kata Kunci- Kebijakan Fiskal, Inflasi, perekonomian indonesia, dampak virus covid 19

\section{PENDAHULUAN}

Wabah Covid-19 mempengaruhi seluruh dunia karena telah menyebar hampir ke 199 negara. Penyebaran virus covid 19 ini berdampak paling besar pada perekonomian yang dilakukan masyarakat maupun pelaku bisnis. Salah satu cara memutus matarantai Covid-19 adalah dengan social distancing, bertujuan mencegah orang sakit melakukan kontak dalam jarak tertentu dengan orang sehat untuk mengurangi penularan. Menurut Center for Disease Control dan Prevention (CDC) AS, social distancing adalah menjauhi perkumpulan, menghindari pertemuan massal, dan menjaga jarak antar manusia sekitar 2 meter. Termasuk bekerja dari rumah (work from home), menutup sekolah/kampus dengan melakukan homeschool- ing/belajar online, dan beribadat di rumah. Social distancing ini, tentunya mengakibatkan kondisi dimana perekonomian global menjadi terganggu.

Di Indonesia sendiri, per tanggal 07 Juli 2020 total kasus virus covid 19 sejumlah 66.226 orang, dengan total pasien sembuh 30.785 orang dan 3.309 Orang (Covid.go.id, 2020). Dalam menghadapi Covid19 , Pemerintah Indonesia melakukan pendekatan yang cepat dan prudent untuk mengurangi dampaknya pada perekonomian. Beberapa ahli mengkhawatirkan, dampak ekonomi yang ditimbulkan oleh Covid-19 bisa lebih besar dari dampak kesehatan, dan pertumbuhan ekonomi akan melambat. Jika terjadi perlambatan ekonomi, maka daya serap tenaga kerja akan berkurang, meningkatnya pengangguran dan kemiskinan (djkn.kemenkeu.go.id, 2020). 
Menteri Keuangan Sri Mulyani mengungkap penyebaran virus corona akan semakin memberatkan perekonomian, dalam kondisi terburuk, Menteri Keuangan Sri Mulyani memperkirakan proyeksi pertumbuhan ekonomi Indonesia berkisar 2,3\% karena virus corona. Namun, skenario terburuknya ekonomi RI dapat minus hingga $0,4 \%$ (cnnindonesia.com, 2020).Mengacu pada Negara berkembang, pemeritah Indonesia mengambil kebijakan yang komperehensif dibidang fiskal.Pada saat ekonomi dirasakanberjalan terlalu lambat dari yang seharusnya yang ditandai dengan rendahnyapertumbuhan dan tingginya tingkat pengangguran, maka dengan kebijakan fiskaldan moneter yang tepat diharapkan dapat mendorong perekonomian tumbuhlebih cepat dan pengangguran dapat ditekan (Ada Tua, 2019). Melalui kebijakan fiskal, Pemerintah Indonesia melakukan kebijakan refocusing kegiatan dan realokasi anggaran yang diharapkan dapat mempengaruhi tingkat pendapatan, distribusi penghasilan, kesempatan kerja dan investasi.

Kebijakan defisit fiskal yang tinggi dapat menyebabkankenaikan tingkat inflasi, sebaliknya perekonomian dengan tingkat inflasi yangtinggi juga memberikan dampak negatif bagi pertumbuhan ekonomi. Perkembangan perekonomian yang semakin dinamis dan terintegrasi denganperekonomian dunia memberikan implikasi penting bagi para pelaku ekonomi terutama dalam pengambilan kebijakan makroekonomi. Pengelolaan kebijakanfiskal dan moneter melalui koordinasi yang baik akan memberikan sinyal positifbagi pasar dan menjaga stabilitas makroekonomi. Kebijakan fiskal dari sisi penerimaan dan pengeluaran terhadap output dan terjadinya inflasi ternyata sangat besar dampaknya akibat virus covid 19 pada perekonomian di Indonesia, oleh karena itu dibutuhkan strategi yang dapat membantu dalam perekonomian yang terjadi saat ini.

\section{Kebijakan Fiskal}

\section{KAJIAN PUSTAKA}

Kebijakan fiskal adalah langkah-langkah pemerintah untuk membuat perubahanperubahan dalam sistem pajak atau dalam pembelanjaannya dengan maksud untuk mengatasi masalah-masalah ekonomi yang dihadapi (Sadono, 2003 dalam Eva dan Muhammad, 2016). Kebijakan fiskal merupakan merupakan kebijakan yang dibuat oleh pemerintah dengan cara meningkatkan atau menurunkan pendapatan atau anggaran negara. Pemerintah memiliki kewenangan untuk menentukan besaran anggaran atau pendapatan yang dikeluarkan pada program tertentu.

Kebijakan ini dibuat dengan maksud untuk mempengaruhi jalannya perekonomian dan menjaga keseimbangan ekonomi dalam negara. Pembuatan kebijakan ini tidak lain didasarkan pada teori John Maynard Keynes mengenai fungsi kebijakan fiskal. Dalam teori ini Keynes meyakini bahwa peningkatan atau penurunan pendapatan dan pengeluaran dapat mempengaruhi perekonomian negara. Kebijakan ini bisa meningkatkan inflasi, aliran kas, dan mengatasi pengangguran dalam suatu negara.Melalui kebijakan ini pengeluaran agregat dapat ditingkatkan yang bisa berdampak pada pendapatan nasional dan tingkat penggunaan tenaga kerja. Selain itu permintaan agregat mengenai jumlah produksi barang dan jasa pada tingkat harga tertentu juga menjadi tolak ukur keberhasilan Negara (Tiara, dkk, 2018). Adapun tujuan Kebijakan Fiskal, yaitu ; (1) pertumbuhan ekonomi, (2) mencegah pengangguran, dan (3) stabilitas harga.

\section{Penerimaan Negara}

Penerimaan negara terdiri dari penerimaan dalam negeri Pemerintah, dan hibah. Penerimaan dalam negeri Pemerintah (Dumairy, 1997 dalam Dina dan Rasinta, 2020) terdiri atas PenerimaanPerpajakan yaitu Pajak dalam negeri berupa ; (a) Pajak Penghasilan (PPh), (b) Pajak Pertambahan Nilai Barang dan Jasa (PPN) dan Pajak Penjualan atas Barang Mewah (PPnBM), (c) Pajak Bumi dan Bangunan (PBB), (d) Bea perolehan Hak atas tanah dan bangunan (BPHTB), (e) Pajak lainnya, (f) Cukai.

\section{Pengeluaran Negara}

Pengeluaran negara adalah semua pengeluaran yang digunakan untuk membiayai kegiatankegiatan pemerintahan suatu negara dalam rangka menjalankan fungsinya agar dapat mewujudkan kesejahteraan pada rakyatnya.

Pengeluaran pemerintah mempunyai dasar teori yang dapat dilihat dari identitas keseimbangan pendapatan nasional yaitu $\mathrm{Y}=\mathrm{C}+\mathrm{I}+\mathrm{G}+(\mathrm{X}-\mathrm{M})$ yang merupakan sumberlegitimasi pandangan kaum Keynesian akan relevansi campur tangan pemerintah dalamperekonomian. Dari persamaan diatas dapat ditelaah bahwa kenaikan atau penurunanpengeluaran pemerintah akan menaikan atau menurunkan pendapatan nasional. Banyakpertimbangan yang mendasari 
pengambilan keputusan pemerintah dalam mengaturpengeluarannya.Teori mengenai pengeluaran pemerintah juga dapat dikelompokanmenjadi 2 bagian yaitu teori makro dan teori mikro. Dalam teori ekonomi makro,pengeluaran pemerintah terdiri dari tiga pos utama yang dapat digolongkan menjadi (Boediono,1998 dalam Dina dan Rasita, 2020):

1. Pengeluaran pemerintah untuk pembelian barang dan jasa;

2. Pengeluaran pemerintah untuk gaji pegawai

3. Pengeluaran pemerintah untuk transfer payment.

Teori Inflasi

Inflasi adalah suatu keadaan perekonomian di suatu negara dimana terjadi kecenderungan kenaikan harga-harga barang dan jasa secara umum dalam waktu yang panjang (kontinu) disebabkan karena tidak seimbangnya arus uang dan barang. Dari definisi tersebut mengindikasikan keadaan melemahnya daya beli yang diikuti dengan semakin merosotnya nilairiil (intrinsik) mata uang suatu negara (Samuelson, 2001 dalam Eva dan Muhammad, 2016).

Faktor-faktor yang mempengaruhi Inflasi, yaitu :

1. Inflasi karena tarikan permintaan (demand pull inflation). Inflasi karena tarikan permintaan (demand pull inflation) ini merupakan inflasi dari sisipermintaan yang disebabkan oleh kenaikan permintaan agregat (pengeluaran rumah tanggakonsumen, investasi, pengeluaran pemerintah dan sektor luar negeri ekspor minus impor).

2. Inflasi karena dorongan penawaran (cost push inflation). Inflasi karena dorongan penawaran (cost push inflation) merupakan inflasi dari sisi penawaranyang disebabkan oleh dorongan biaya produksi (cost push) maupun distorsi distribusi karenastruktur pasar yangmonopolitis-oligopolistis, keduanya akan dapat menghambat penawaranagregat.

\section{Hubungan Kebijakan Fiskal, Output, dan Inflasi}

Kebijakan fiskal Negara Indonesia tercermin dalam Anggaran Pendapat Belanja Negara (APBN). Dalam APBN tersebut, terdapat penetapan pemerintah mengenai alokasi dan distribusi keuangan negara. Mengingat urgennya bidang ini dalam pembangunan perekonomian negara. Kebijakan fiskal juga berpengaruh terhadap inflasi (Dina dan Rasinta, 2020). Literatur yang ada mengelompokkan dampak kebijakan fiskal menjadi dua yaitu dampak terhadap sisi permintaan (demand side effect) dan dampak terhadap sisi penawaran (supply side effect). Dampak kebijakan fiscal terhadap sisi penawaran mempunyai implikasi jangka panjang. Kebijakan fiskal yang berorientasi un- tuk meningkatkan supply side dapat mengatasi masalah keterbatasan kapasitas produksi dan karena itu dampaknya lebih bersifat jangka panjang.

Pendekatan Keynesian mengasumsikan adanya price rigidity dan excess capacity sehingga outputditentukan oleh permintaan agregat (demand driven). Keynes menyatakan bahwa dalam kondisi resesi, perekonomian yang berbasis mekanisme pasar tidak akan mampu untuk pulih tanpa intervensi dari Pemerintah. Oleh karena itu, dalam pendekatan ini, kebijakanfiskal dapat menggerakkan perekonomian dengan peningkatan pengeluaran pemerintahatau pemotongan pajak yang mempunyai efek multiplier dengan cara menstimulasi tambahanpermintaan untuk barang konsumsi rumah tangga (fiscuswannabe.web.id, 2013).

Demikian pula halnya apabila pemerintah melakukan pemotongan pajak sebagai stimulus perekonomian. Pemotongan pajak akan meningkatkan disposable income dan pada akhirnya mempengaruhi permintaan. Kecenderungan rumah tangga untuk meningkatkan konsumsi dengan meningkatkan marginal prospensity to consume $(\mathrm{mpc})$, menjadi rantai perekonomian untuk peningkatan pengeluaran yang lebih banyak dan pada akhirnya terhadap output (Dina dan Rasinta, 2020).

\section{METODE PENELITIAN}

Penelitian ini dilakukan dengan menggunakan metode kualitatif. Penelitian kualitatif merupakan metode pengumpulan dan analisa datanya bersifat non kuantitatif dengan tujuan untuk mengeksplorasi hubungan sosial dan deskripsi realitas yang dialami respon (Saraclaers, 1993). Sedangkan menurut Sugiyono (2005) penelitian kualitatif adalah penelitian yang bermaksud untuk memahami fenomena tentang apa yang dialami oleh subjek penelitian misalnya perilaku, persepsi, motivasi, tindakan, dll secara holistic, dan dengan cara deskripsi dalam bentuk kata-kata dan bahasa, pada suatu konteks khusus yang alamiah dan dengan memanfaatkan berbagai metode alamiah.

Pada penelitian ini, peneliti memilih menggunakan tipe penelitian deskriptif, yaitu untuk menjelaskan suatu peristiwa yang operasionalisasinya berkisar pada pengumpulan data, pengolahan data dan penafsiran data yang diberi makna secararasional dengan tetap memegang prinsip-prinsip logika sehingga terbentuk kesimpulan yang holistik. Data diperoleh melalui studi literatur, dengan membaca dan menelaah serta menganalisa berbagai literatur, baik berupa dokumen, jurnal, data publikasi dari kementerian keuangan maupun dari website resmi yang 
mengeluarkan informasiinformasi yang relevan terhadap penelitian. Sementara analisa data dilakukan denganmelakukan reduksi, klasifikasi, pemaknaan hingga penarikan kesimpulan.

\section{HASIL DAN PEMBAHASAN}

Kebijakan Fiskal Untuk Penerimaan Negara

Realisasi penerimaan pajak hingga akhir Mei 2020 masih tercatat turun 10,8\% dibandingkan periode yang sama tahun lalu. Penurunan tersebut tercatat makin dalam dibandingkan dengan akhir bulan sebelumnya 3,1\%. Hal ini dipaparkan Menteri Keuangan Sri Mulyani Indrawati melalui video conference APBN, bahwa realisasi penerimaan pajak hingga akhir Mei 2020 senilai Rp444,6 triliun atau 35,4\% terhadap target APBN 2020 yang sudah diubah sesuai Perpres No. 54 /2020 senilai Rp1.254,1 triliun. Berikut ditunjukkan pada grafik dibawah ini :

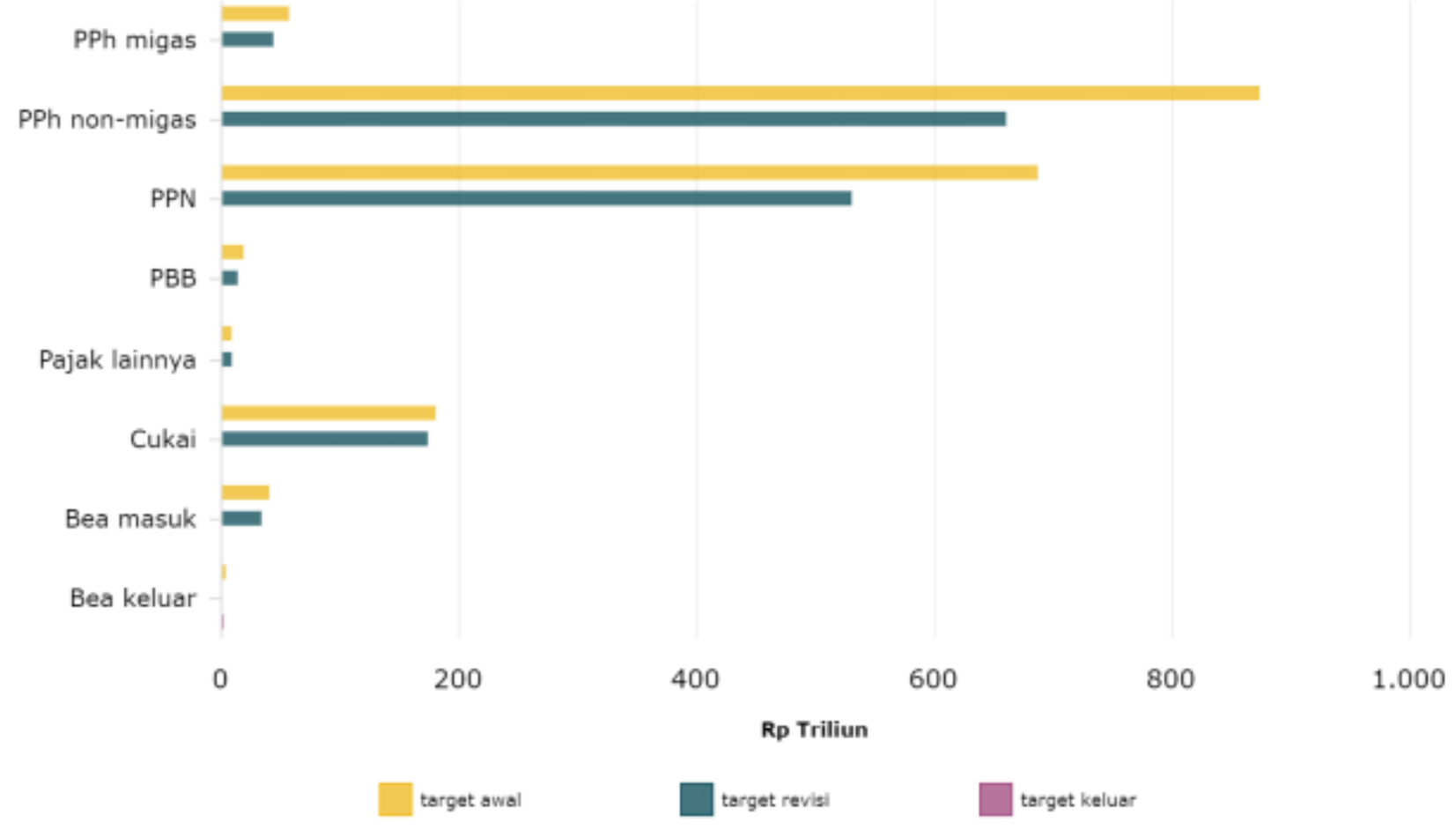

\section{Sumber Data : Kementrian Keuangan, 2020.}

Menteri keuangan mengeluarkan Peraturan Menteri Keuangan Nomor 23 Tahun 2020 (PMK 23 Tahun 2020) tentang instentif pajak untuk wajib pajak terdampak wabah Virus Covid-19. Pemberian insentif ini sebagai respon dari pemerintah atas menurunnya produktivitas para pelaku usaha karena roda perekonomian wajib pajak yang menurun drastis akibat wabah ini (Dina dan Rasita, 2020).Sebagaimana yang terjadi di Indonesia, penerimaan pajak pada kuartal I-2020 tercatat mengalami kontraksi atau minus hingga 2,5\%. Adapun beberapa instrumen pajak yang minus setelah digunakan untuk penanganan Covid-19 adalah PPh Badan dan Pajak dalam rangka Impor (PDRI) terdiri beberapa jenis, yaitu Pajak Penghasilan (PPh) pasal 22 impor, PPh pasal 22 ekspor, Pajak Pertambahan Nilai (PPN) impor, dan Pajak Penjualan Barang Mewah (PPnBM).

Menteri Keuangan (Menkeu) Sri Mulyani Indrawati menyatakan, pemerintah bakal menanggung pembayaran Pajak Penghasilan $(\mathrm{PPh})$ Pasal 21. Kebijakan bebas pajak ini mulai berlaku April 2020. Ini merupakan salah satu paket stimulus kebijakan pemerintah untuk mencegah perlambatan ekonomi lebih jauh akibat wabah virus corona. Tiga kebijakan lain merupakan penangguhan pembayaran untuk $\mathrm{PPH}$ Pasal 22, PPh pasal 25 serta restitusi dipercepat untuk Pajak Penghasilan (PPN).Bagi wajib pajak yang melakukanaktivitas imporakan diberikan pembebasan PPh Pasal 22 impor selama 6 bulan.Pemberian fasilitas ini diberikan melalui Surat Keterangan Bebas (SKB) PPh Pasal 22Impor kepada wajib pajak.

Sedangkan penurunan tarif merupakan konsekuensi dari Peraturan Pemerintah Pengganti Undang-Undang (Perppu) No. 1/2020 yang menurunkan tarif PPh Pasal 25 menjadi 22\% pada 2020 dan 2021 dan menjadi $20 \%$ pada 2022, satu tahun lebih cepat dari yang direncakan dalam Omnibus Law Perpajakan.

Untuk penerimaan Kepabeanan dan Cukai, secara nominal realisasinya masih tumbuh sebesar 
Rp57,7 triliun atau 27,7\% dari target APBN-Perpres $54 / 2020$. Penerimaan ini didukung utamanya oleh penerimaan dari Cukai sebesar Rp36,2 triliun. Sementara itu, realisasi perdagangan internasional sampai dengan bulan April 2020 tumbuh negatif, dimana realisasi Bea Masuk tumbuh negatif 2,64 \% atau sebesar Rp11,5 triliun dan realisasi Bea Keluar tumbuh negatif 34,97 \% atau sebesar Rp0,9 triliun. Pertumbuhan perpajakan perdagangan internasional ini terjadi akibat turunnya volume impor, penurunan harga komoditas, dan melambatnya aktivitas ekspor barang mineral nikel dan tembaga sebagai dampak mewabahnya Covid-19 di berbagai negara. Hal ini juga tercermin dari Neraca Perdagangan Indonesia di bulan April yang mengalami defisit sebagai akibat dari tekanan defisit di sisi migas maupun non migas (kemenkue.go.id, 2020).

Di sisi lain, belanja negara per Mei 2020 tercatat senilai Rp843,9 triliun atau 32,3\% dari pagu Rp2.613,8 triliun. Realisasi belanja negara itu hanya tumbuh negatif $1,4 \%$ dibandingkan penyerapan per akhir Mei tahun lalu yang senilai Rp855,9triliun.Dengan performa pendapatan negara dan belanja negara itu, defisit APBN tercatat mencapai Rp179,6triliun atau 21,1\% dari patokan dalam APBN 2020 senilai Rp852,9triliun. Realisasi defisit anggaran itu setara dengan 1,10\% PDB (news.ddtc.co.id, 2020).

\section{Kebijakan Fiskal Untuk Pengeluaran Negara}

Pada masa pandemic covid 19, pemerintah mengambil kebijakan (Dhyaksa, 2020) yaitu : dukungan terhadap bidang kesehatan, insentif bulanantenaga medis, perlindungan sosial, tariff listrik, menaikkan anggaran kartu pra kerja,pemulihan ekonomi, antisipasi defisit APBN, nasabah KUR dapat keringanan angsuran, bidang non fiskal, refokusing dan relokasi belanja, menyiapkan Perpu.Selanjutnya, Kementerian Keuangan akan merealokasi dana APBN sebesar Rp62,3 triliun.

Dana tersebut diambil dari anggaran perjalanan dinas, belanja non operasional, honor-honor, untuk penanganan/pengendalian Covid-19, perlindungan sosial (social safety net) dan insentif dunia usaha. APBD juga diharapkan di-refocusing dan realokasi untuk 3 hal tersebut.Penguatan penanganan Covid-19, dilakukan dengan menyediakan fasilitas dan alat kesehatan, obat-obatan, insentif tim medis yang menangani pasien Covid-19 dan kebutuhan lainnya. Social safety net diberikan untuk meningkatkan daya beli masyarakat melalui program keluarga harapan (PKH), Kartu Indonesia Pintar (KIP), Kartu Sembako dan beras sejahtera (kemenkue.go.id, 2020).
Pemerintah memproyeksikan peningkatan pembiayaan anggaran menjadi Rp. 852,9 Triliun karenadampak pandemi Covid-19 Angka tersebut naik Rp. 547 Trilun dari Anggaran Pendapatan dan Belanja (APBN) 2020. Defisit APBN melebar 5,07\% dari PDB.Pembiayaan invetasi juga bertambah. Dari minus 74,2 triliun menjadi minus 229,3 triliun.

Berdasarkan bahan paparan Kementerian Keuangan (Kemenkeu), pembiayaan anggaran tahun ini naik Rp 186,3 triliun dari Peraturan Presiden (Perpres) Nomor 54 tahun 2020 yang sebesar Rp 852,9 triliun menjadi Rp 1.039,2 triliun. Hal ini sudah sesuai dengan besaran outlook defisit APBN 2020. Pembiayaan utang tercatat naik Rp 213,9 triliun dari Rp 1.006,4 triliun menjadi Rp 1.220,3 triliun. Outlook pembiayaan utang ini naik, untuk membiayai pelebaran defisit anggaran dan tambahan pembiayaan investasi. Pembiayaan investasi tercatat naik Rp 24,6 triliun dari $\mathrm{Rp}$ 229,3 triliun menjadi Rp 253,9 triliun. Ini sudah termasuk tambahan pembiyaan investasi BUMN yang menjadi bagian pendanaan program pemulihan ekonomi nasional (katadata.go.id, 2020).

Mengatasi dampak ekonomi dari wabah Covid-19 terhadap perekonomian Indonesia akan sangat ditentukan oleh pilihan kebijakan dan kesigapan pemerintah untuk mengatasi wabah tersebut [1]. Perbedaan tingkat fatality rate di berbagai negara juga menjadi pelajaran berharga bahwa kebijakan pemerintah sangat menentukan dalam mengatasi pandemi ini,selain dukungan sistem dan perilaku masyarakat.Beberapa langkah yang sebaiknya dilakukan pemerintah untuk efisiensi sisi pengeluaranyaitu, (Dina dan Rasinta, 2020) :

1. Penerbitan Surat Utang (SUN) Dalam Angka Rupiah Untuk Menekan Pembayaran Bunga.

2. Melakukan Refocusing APBN 2020

3. Konsekuensi Hukum Terhadap Penyelewengan Dana Penanggulanan Covid-19

\section{Strategi Kebijakan Fiskal Terhadap Output Perekonomian Indonesia}

Pendekatan Keynesian mengasumsikan adanya price rigidity dan excess capacity sehingga outputditentukan oleh permintaan agregat (demand driven). Keynes menyatakan bahwadalam kondisi resesi, perekonomian yang berbasis mekanisme pasar tidak akan mampu untuk pulihtanpa intervensi dari Pemerintah. Dalam pendekatan Keynes, kebijakan fiskal dapat menggerakkan perekonomian karena peningkatan pengeluaran pemerintah atau pemotongan pa- 
jak mempunyai efek multiplier dengan cara menstimulasi tambahan permintaan untuk barang konsumsi rumah tangga.

Demikian pula halnya apabila pemerintah melakukan pemotongan pajak sebagai stimulus perekonomian. Pemotongan pajak akan meningkatkan disposable incomedan pada akhirnya mempengaruhi permintaan. Kecenderungan rumah tangga untuk meningkatkan konsumsi dengan meningkatkan marginal prospensity to consume (Nurul, 2010).

Sejalan dengan strategi yang dilakukan pemerintah, hal ini dibuktikan dengan komitmen pemerintah untuk terus menjaga keberlanjutan fiskal di tahun 2020. Realisasi defisit APBN hingga April 2020 mencapai Rp74,47 triliun atau sekitar 0,44 \% PDB. Realisasi pembiayaan anggaran hingga April 2020 mencapai Rp221,84 triliun dan mengalami peningkatan sebesar $53,58 \%$, terutama bersumber dari pembiayaan utang (kemenkeu.go.id, 2020).

\section{Strategi Kebijakan Fiskal Terhadap Inflasi Perekonomian Indonesia}

Inflasi dapat digolongkan menjadi empat golongan yakni inflasi ringan, sedang, berat dan hiperinflasi. Inflasi ringan terjadi bila kenaikan harga berada di bawah angka $10 \%$ setahun, inflasi sedang antara 10\%-30\% setahun, inflasi berat antara 30\%-100\% setahun, dan hiperinflasi atau inflasi tak terkendali terjadi apabila kenaikan harga berada di atas $100 \%$ setahun. Dalam masa pandemic covid 19 yang berdampak pada sector bisnis, terutama pada sector pariwisata dan sector manufaktur.

Sektor manufaktur juga terimbas karena terhambatnya supply chain bahan baku disebabkan kelangkaan bahan baku terutama dari China dan keterlambatan kedatangan bahan baku. Hal ini akan berdampak pada kenaikan harga produk dan memicu inflasi.

Pada masa pandemic ini, pemerintah mengambil kebijakan yang tertuang dalam 3 stimulus fiskal, yaitu :

1. Pada Februari, pemerintah memberikan stimulus Rp 8,5 triliun untuk memperkuat ekonomi dalam negeri melalui sektor pariwisata.

2. Pada pertengahan Maret, pemerintah kemudian meluncurkan stimulus lanjutan senilai Rp 22,5 triliun. Stimulus ini berupa kebijakan fiskal dan nonfiskal untukmenopang sektor industri dan memudahkan ekspor-impor.

3. Pada akhir Maret, pemerintah menetapkan pembatasan sosial berskala besar (PSBB)untuk menangani penyebaran virus. Stimulus Rp 405,1 triliun juga dikeluarkanmendampingi kebijakan kesehatan itu.
Dana tersebut digunakan untuk, (a) Sekitar Rp 150 triliun untuk pembiayaan program pemulihan ekonomi nasional seperti restrukturisasi kredit dan penjaminan serta pembiayaan untuk UMKM dandunia usaha, (b) Rp75 triliun untuk bidang kesehatan, meliputi perlindungan tenaga kesehatan, pembelian alat kesehatan, perbaikan fasilitas kesehatan, dan insentif dokter, (c) Rp110 triliun untuk jaring pengaman sosial (social safety net), untuk menambah manfaat bantuan sosial, pembebasan biaya listrik, dan dukungan kebutuhanpokok, (d) Rp70,1 Triliun untuk pengurangan tarif pajak penghasilan dan penundaan pembayaran KUR (Kemenkue.go.id, 2020).

Riset di Bank Indonesia, (2009) membuktikan bahwa kebijakan fiskal Indonesia cenderung bersifat asiklikal secara agregat atau justru prosiklikal jika berdasarkan pengelompokan pengeluaran. Sifat siklikalitas yang demikian berpotensi memberikan tekanan instabilitas dalam perekonomian, seperti kenaikan inflasi. Plotting antara rasio pengeluaran pemerintah, dengan tidak memasukkan pembayaran bunga, dengan pertumbuhan ekonomi menunjukkan adanya Siklikalitas Kebijakan Fiskal di Indonesia.

Oleh karena itu, untuk memperkuat pasar domestik, Pemerintah telah melakukan sinergi dengan Bank Indonesia melalui Surat Keputusan Bersama (SKB) Nomor 190/KMK.08/2020 antara Menteri Keuangan dengan Gubernur Bank Indonesia, sebagai pelaksanaan dari ketentuan Perppu Nomor 1 Tahun 2020 tentang Kebijakan Keuangan Negara dan Stabilitas Keuangan untuk Penanganan Pandemi Covid-19 dan/atau dalam rangka Menghadapi Ancaman yang Membahayakan Perekonomian Nasional dan/atau Stabilitas Sistem Keuangan yang baru saja ditetapkan menjadi Undang-Undang Nomor 2 Tahun 2020. Dalam ketentuan yang terdapat pada SKB tersebut, BI dapat membeli Surat Berharga Negara (SBN) jangka panjang yang bersifat tradable di pasar perdana. Selama bulan April, SKB tersebut telah diimplementasikan sebanyak dua kali, yaitu pada rangkaian lelang Surat Berharga Syariah Negara (SBSN) tanggal 21 April 2020 dan lelang Surat Utang Negara (SUN) tanggal 28 April 2020. Pemerintah juga sudah meluncurkan program Pemulihan Ekonomi Nasional (PEN) dalam PP nomor 23 tahun 2020 sebagai upaya untuk menggerakkan perekonomian, melindungi, mempertahankan, dan meningkatkan kemampuan ekonomi pelaku usaha baik di sektor riil maupun sektor keuangan, termasuk kelompok usaha mikro, kecil, dan menengah (UMKM).

Selain itu, baru-baru ini pemerintah mengeluarkan kebijakan new normal berdasarkan Surat 
Edaran (SE) Menteri Kesehatan Nomor HK.02.01/Menkes/335/2020 tentang Sektor Jasa dan Perdagangan (Area Publik) dalam Mendukung Keberlangsungan Usaha. Pemerintah menargetkan, pertumbuhan ekonomi Indonesia bisa tetap positif pada kuartal II dan kuartal III 2020 di ambang 2,3\%-2,5\%. Penerapan new normal diharapkan dapat menyokong pertumbuhan ekonomi tersebut. Dengan beroperasinya sektor industri, perekonomian dapat bergeliat kembali dan mengatrol pertumbuhan ekonomi.

\section{KESIMPULAN DAN SARAN}

Pemerintah Indonesia mengambil kebijakan yang komprehensif di bidang fiskal dan moneter untuk menghadapi Covid-19. Di bidang fiskal, Pemerintah melakukan kebijakan refocusing kegiatan dan realokasi anggaran. Dari sisi penerimaan, pemerintah harus memperhatikan pemberian kontribusi penerimaan dari PPN dan PPh Badan dan dari sisi pengeluaran, pemerintah harus mampu memperhatikan realisasi penggunaan dana tersebut agar tepat sasaran dan mengutamakan kegiatan prioritas pencegahan pandemik Covid-19 Untuk menekan defisit anggaran.

Strategi kebijakan fiskal yang berpengaruh terhadap output dan inflasi pada perekonomian Indonesia dapat dilihat dari kebijakan pemerintah yang tertuang dalam 3 stimulus. Pembiayan-pembiayan pemerintah dapat melakukan refocusing/revisi terhadap anggaran yang ada di APBN untuk dioptimalkan penggunaannya selama masa pandemic Covid-19. Selain itu, dengan kebijakan new normal baru-baru ini, diharapkan dapat menyokong pertumbuhan ekonomi tersebut. Dengan beroperasinya sektor industri, perekonomian dapat bergeliat kembali dan mengatrol pertumbuhan ekonomi.

\section{REFERENSI}

[1] A. Solihat, "How Behavioral Finance during Pandemic," BIEJ Bus. Innov. Entrep. J., vol. 2, no. 2, pp. 131-137, 2020.

[2] Ada Tua Pardamean. 2019. Dampak Kebijakan Fiskal dan Moneter Dalam Perekonomian Indonesia. Program Pascasarjana Universitas Medan.
[3] Cnnindonesia.com. 2020. Diakses 4 Juli

[4] Dina Eva, dan Rasinta Ria. 2020. Strategi Kebijakan Fiskal Pemerintah Indonesia dalam Menghadapi Dampak Pandemi Covid 19. Jurnal Ekonomi dan Ekonomi Syariah. Vol 3 No 2 ISSN : 2614-3259.

[5] Djkn.kemenkeu.go.id. 2020. Diakses 4 Juli.

[6] Dumairy. (1997). Perekonomian Indonesia. Jakarta: Erlangga.

[7] Eva Dayanti, dan Muhammad Nasir. 2016. Dampak Kebijakan Fiskal Regional Terhadap Output dan Inflasi di Kota Banda Aceh.Jurnal Ilmiah Ekonomi Pembangunan Fakultas Ekonomi dan Bisnis Unsyiah.

[8] Katadata.go.id. 2020. Diakses 06 Juli.

[9] Kemenkeu.go.id. 2020. Diakses 07 Juli. Kebijakan Fiskal dan Moneter Menanggapi Dampak Covid 19.

[10] Nainggolan, E. U. (2020, April). Kebijakan Fiskal dan Moneter Menghadapi Dampak Covid-19.

[11] News.ddtc.co.id. 2020. Diakses 6 Juli.

[12] Nurul, Amin. 2010. Dampak Kebijakan Fiskal Terhadap Output dan Inflasi. Jurnal STIE Syariah Bengkalis.

[13] Tiara Juniar, dkk. 2018. Analisis Hubungan Kebijakan Fiskal Dan Makroekonomi Daerah Kabupaten/Kota Jawa Timur. Simposium Keuangan Negara.

[14] Sadono Sukirno. (2013). Teori Pengantar Makro Ekonomi. Jakarta: PT. Raja Grafindo Perkasa.

[15] Syamsi, I. (1983). Dasar-dasar Kebijaksanan Keuangan Negara. Jakarta.

[16] Sugiyono. 2015. Statitika Untuk Penelitian. Bandung; Alpha Beta. 